ACTA MYCOLOGICA

Vol. 41 (2): 177-188

2006
Dedicated to Professor Alina Skirgietto

on the occasion of her ninety fifth birthday

\title{
Hebelomina neerlandica, a new species for Ukraine and considerations about the genus Hebelomina
}

\author{
ANDRÉ FRAITURE ${ }^{1}$ and VERA HAYOVA ${ }^{2}$
}

${ }^{1}$ Jardin Botanique National de Belgique

Domaine de Bouchout, B 1860 Meise, fraiture@br.fgov.be

${ }^{2}$ Department of Mycology, M. G. Kholodny Institute of Botany,

National Academy of Sciences of Ukraine

Tereshchenkivska 2,01601 Kiev, veha@ln.ua

Fraiture A., Hayova V.: Hebelomina neerlandica, a new species for Ukraine and considerations about the genus Hebelomina. Acta. Mycol. 41 (2): 177 188, 2006.

Hebelomina neerlandica Huijsman has been found near Kiev (Ukraine). It is an addition to the Ukrainian mycoflora. The specimens are described and illustrated. A synopsis of the genus Hebelomina is presented, with comments on the systematics and the distribution of its different species, which are all very rare.

Key words: Hebelomina, Hebeloma, Gymnopilus, Rapacea, Cortinariaceae, Ukraine

\section{INTRODUCTION}

During a mycological excursion in a forest near Novobilychi (Kiev, Ukraine), a whitish gilled mushroom has been observed. It was growing on a dead log of Pinus sylvestris lying on the ground. Several sporophores have been collected. Their characters are typical of Hebelomina neerlandica Huijsman, a.o. the general habit, whitish colour, ecology, size and shape of the cheilocystidia, size and shape of the spores, which are smooth, whitish and dextrinoid. This species has never been reported from Ukraine. A short description of the specimens is given below.

Up to now, six species have been described in the genus Hebelomina, most of them are extremely rare or even known only by the type specimens. The taxonomic position of the genus and its species is still under discussion. The nomenclature is also quite complicated. A summary of the data concerning those questions is presented here as well as a list of the descriptions and illustrations published for the different species, an overview of their worldwide distribution and an identification key. 


\section{DESCRIPTION OF THE UKRAINIAN COLLECTION}

Sporophores completely whitish, drying ochraceous, sometimes with a rather dark rusty brown spot. Pileus $12-22 \mathrm{~mm}$ broad, convex with involute margin, smooth, moist, not viscid. Lamellae adnate. Stipe $12-25 \times 2-4.5 \mathrm{~mm}$, central, cylindrical, curved, without annulus, small remnants of a cortina-like velum sometimes visible on young specimens. Context whitish. No particular smell detected. Taste not tested.

Spores (Figs 1a and 2) (6.0-) 6.5-7.5 (-8.0) x (3.5-) 4.0-4.5 (-5.1) $\mu \mathrm{m}$, generally amygdaliform, sometimes ellipsoid or ovoid, hyaline, smooth, without germ-pore, slightly thick-walled, dextrinoid (reddish-brown in Melzer reagent). Basidia (Fig. 1b) irregularly cylindrical, (2-) 4-spored, 28-30 x 5-7 $\mu \mathrm{m}$, with sterigmata 4-6 $\mu \mathrm{m}$ long. Cheilocystidia (Fig. 1c) usually narrowly lecythiform, sometimes narrowly lageniform, narrowly conical or cylindrical, 25-35 x 5.0-6.5 $\mu \mathrm{m}$ (body), x 2.0-3.0 $\mu \mathrm{m}$ (neck) and x 2.5-4.5 $\mu \mathrm{m}$ (head). Pleurocystidia absent. Clamp-connections present.

ECOLOGY. Sporophores not caespitose, growing on a fallen dead trunk of Pinus sylvestris, in a forest of Pinus sylvestris with numerous Quercus robur, on podsolic sand.

SPECIMEN DESCRIBED. Ukraine, Kiev, forest near Novobilychi, 14. IX. 2004. Herbarium A. Fraiture 2927 (BR), double in herb. V. Hayova (KW 29993).

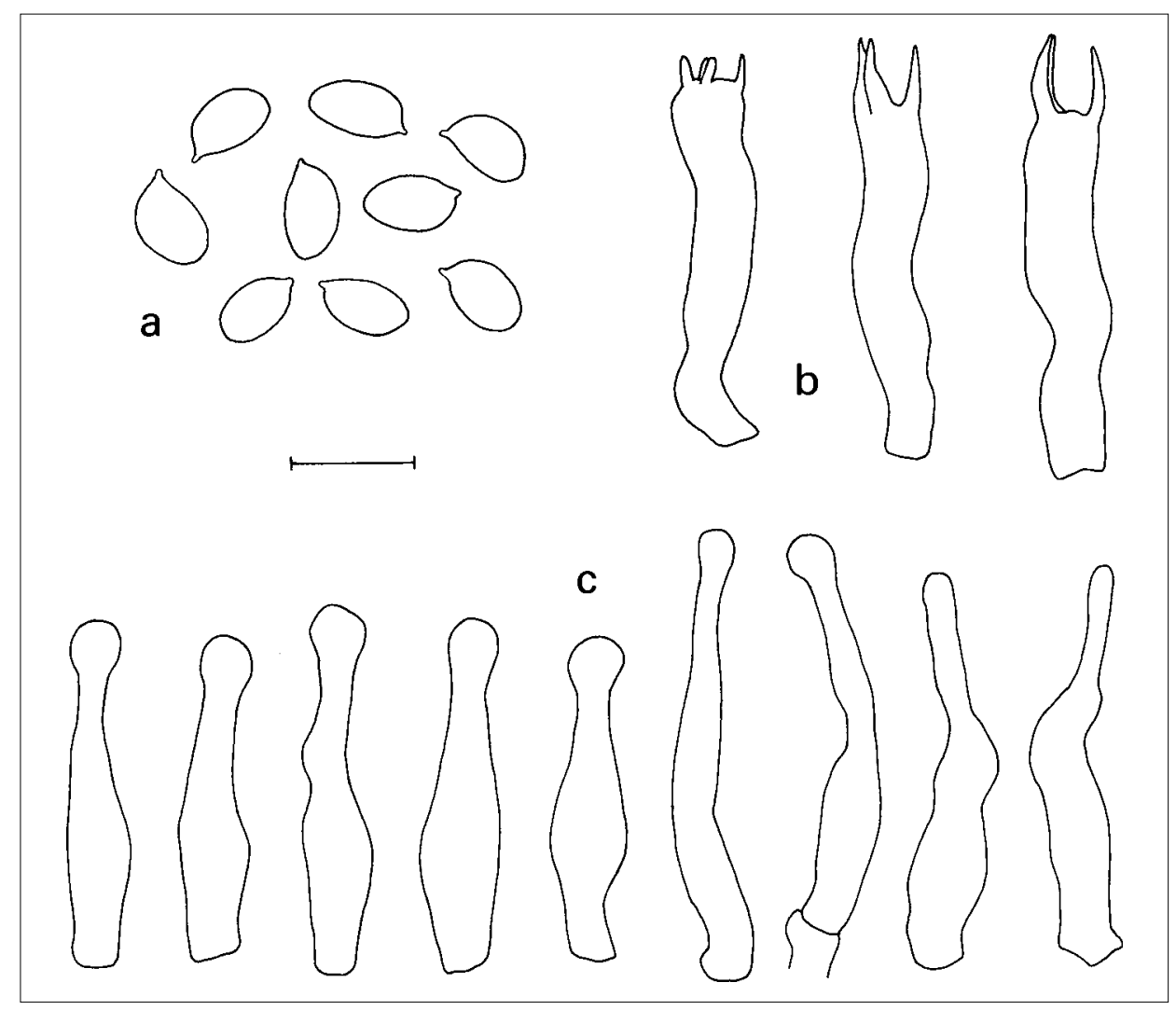

Fig. 1. Hebelomina neerlandica: a spores, b basidia, c cheilocystidia (specimen A. Fraiture 2927, BR); scale bar $=10 \mu \mathrm{m}$. 


\section{SYNOPSIS OF THE GENUS HEBELOMINA}

Genus Hebelomina Maire 1935, Bull. Soc. Hist. nat. Afrique du Nord 26: 13. $\equiv$ Hebeloma [sect. Denudata] subsect. Hebelomina (Maire) Beker, Eberhardt and Vesterholt 2005, in Vesterholt, The genus Hebeloma: 24 [note: this is probably the correct name]. Type species: Hebelomina domardiana Maire.

The taxonomic position of the genus Hebelomina is not easy to circumscribe and the question has been treated by several authors. The most argumented discussion is probably the one proposed by Singer (1986: 611), who finally decides to accommodate the genus in the Cortinariaceae, where he assumes it is related to Cortinarius and Leucocortinarius or, more probably, to Hebeloma. The difficulty in positioning the genus in the systematics is partly due to its very specific characters, a.o. the spores which are whitish, smooth, thick walled, devoid of a pore and dextrinoid.

As it will be seen hereunder, the problem also lies in the fact that the genus Hebelomina is heterogenous. H. domardiana, type species of the genus Hebelomina, seems to be a white spored Hebeloma. Consequently, the genus Hebelomina has been recently included in Hebeloma (Vesterholt 2005). However, it will not be possible to transfer to Hebeloma all the species described in Hebelomina. Molecular analysis (Mon calvo et al. 2002: 367, 379) has shown that Hebelomina neerlandica is probably a Gymnopilus. Those authors extend however improperly their conclusions to the whole genus Hebelomina.

? Hebelomina amazonensis Sing. 1979, in Singer and Araujo, Acta amazonica 9 (1): 32 [invalid: nomen nudum].

This is a simple mention of the name, without any description or citation of a specimen. Singer did not cite the name in his Agaricales in Modern Taxonomy, ed. 4 (1986) and one may thus suppose that he did not believe anymore in the value of this taxon.

Hebelomina domardiana Maire 1935, Bull. Soc. Hist. nat. Afrique du Nord 26: 13. 三Hebeloma domardianum (Maire) Beker, Eberhardt and Vesterholt 2005, in Vesterholt, The genus Hebeloma: 102 [note: this is probably the correct name of the species]. Descriptions: Maire (1935, original description), Ves te r holt (2005), U rb on as (2005: 174). ILLUSTRATIONS: Maire (1935, line drawings of the specimens and microscopic characters), Vesterholt (2005, aquarelle of the specimen and line drawings of spores and cheilocysti dia), Urbon as (2005, pl. 21,1: a f, aquarelle of the specimens and line drawings of micro scopic characters).

Maire (1935), in the first lines of his paper, already says that H. domardiana is «un Champignon très remarquable, ayant l'aspect extérieur d'un Tricholoma, mais qui est, en réalité, un Hebeloma à spores incolores». The great mycologist also points out that the genus Hebelomina «est aux Hebeloma ce que le genre Cortinellus [ Leucocortinarius] est aux Cortinarius». He adds in his comments that the amygdaliform spores, with an epispore rigid and thin but looking double, becoming violaceouspurple by iodine when young, the edge of the gills entirely covered with filamentous subclaviform and very dense hairs and even the faint raddish smell and the bitterness of the flesh are characters of Hebeloma. It is possible to add other characters corresponding with the genus Hebeloma: big spores $(11-15 \times 8 \mu \mathrm{m})$ with a clearly papil- 
late top, white cap becoming reddish brown in the centre, white stem very pruinose under the gills ("valde pruinosa", in italics in the latin diagnosis), tricholomoid habit and terricolous ecology. Ge nn ari (2003) says "su legno di Quercus suber", but the original description gives no indication concerning lignicolous ecology. Moreover, Maire compares his species with Hebeloma and Tricholoma and tells that, at first sight, he took it for Hygrophorus eburneus var. pseudodiscoideus; all of those fungi are terricolous.

Molecular analysis recently confirmed the intuition of Maire and showed that, despite its white spores, Hebelomina domardiana probably belongs to the genus $\mathrm{He}$ beloma, where it occupies however a "very isolated position" (Vester holt 2005).

Unfortunately, it seems that the type specimen, collected by Maire, has not been preserved or is lost. Therefore, Vesterholt had to undertake molecular study of material collected in Estonia. The species has also been reported from Lithuania and Latvia (Urbonas, Kalamees, Lukin 1986). If there is no problem to admit that the different collections from the three Baltic states belong to the same taxon, it is less easy to believe that a species growing in the Baltic states can also be present in a Quercus suber wood in Algeria, especially for a taxon which is most probably mycorrhizal. If the type material can not be found again, it would be interesting to make a new collection of the species in its original growth place or in a Quercus suber wood of the Mediterranean region.

DistRIBUTION: ALGERIA: Forêt de l'Alma, 15. XII. 1933, under Quercus suber (Maire 1935). Maire says "Mauritaniae" but l'Alma is situated about $40 \mathrm{~km}$ to the east of Alger; its name is now Boudouaou (P. Bertea and J.F. Trimbach, comm. pers.). No herbarium specimen is formally cited in the protologue. After Hor ak (1968: 266) and Hu ij s m an (1978: 487), the type specimens have been lost. ESTONIA: Surju, 28. VIII. 1989, in mixed forest, specimen Vesterholt JV89 497 (Vester holt 2005: 133). LATVIA: on humus in pine forests; no locality and no collecting date indicated (U rb on as et al. 1986: 71). Ge nn ari (2003) men tions a personal communication from Kalamees, after which the collections have been lost. After Nezdoimin ogo (1996), those records are quite doubtful. LITHUANIA (U rbo n as 2005: 174): Rūdininkų, Šalčininkų distr., 03.VIII.1974, in mixed forest with Pinus, young Quercus and Betula. Viešvilés reserve, Jurbarko distr., 19.VII.2000, young Picea abies forest.

Biržų forest, Biržų distr., 16.VIII.2001, in mixed forest. See also U rb on as et al. (1986: 71 , cf. comments given here above for Latvia)

Hebelomina maderaspatana Natarajan and Raman 1980, Kavaka 8: 72.

DesCRIPTIONS AND ILlUSTRATIONS: N a ta r a ja n and R a m an (1980, original description and line drawings of the specimens, spores and basidia). The text and the illustrations, except the latin description, are reproduced in Natarajan and Raman (1983: 137138 et Fig. 22, e g).

The classification of this species is very unclear. The limoniform and rather big spores $(7-11.2 \times 5.6-8.4 \mu \mathrm{m})$ are quite typical of Hebeloma while the presence of rhizomorphs at the base of the stem indicates rather a saprotrophic species growing on litter or in connection with wood. On the other hand, the reddish-brown to orange-brown colours are rather resembling the genus Gymnopilus. Moreover, the lack of cheilocystidia corresponds neither with Hebeloma nor with Gymnopilus and therefore $H$. maderaspatana could belong to another genus.

DistRIBUTION: INDIA: campus of the Indian Institute of Technology, Guindy (Madras), 23. VIII. 1978, on ground, in groups, coll. N. Raman (MUBL 2421, paratypus) Ibid., 3.XI.1978, on lit ter, in groups, coll. N. Raman (MUBL 2420, holotypus) (N a t a r a a a , R a m a n 1980, 1983). 
Hebelomina mediterranea A. Gennari “2002”, publ. 2003, Riv. Micol. 45 (4): 312. Descriptions and illustrations: Ge nnari (2003, original description and colour photo graph of the specimens, spores, cheilocystidia and epicutis; line drawings of the spores, ba sidia, cheilocystidia and epicutis).

The big limoniform to subamygdaliform spores, measuring 9-11 (-12) x 6-8 (-8.5) $\mu \mathrm{m}$, the subclavate to cylindrical cheilocystidia, the milky white cap, with a cream ochraceous centre, the stem pruinose on the apex, the tricholomatoid habit and the terricolous ecology are connecting the species with the genus Hebeloma. It is very probable that its pertaining to this genus will be demonstrated.

The species appears to be very close to $H$. domardiana. The comparison of the descriptions (Gennari 2003; Maire 1935; Urbonas 2005; Vesterholt 2005) shows only a few differences between the two species. The specimen of $H$. mediterranea is more robust than $H$. domardiana (cap diameter $5-7 \mathrm{~cm}$ versus $2.5-4 \mathrm{~cm}$ ) and its spores are slightly shorter: 9-11 (-12) $\mu \mathrm{m}$ instead of 11-15 or 10.7-13.4 $\mu \mathrm{m}$. Gennari also mentions a germ-pore ("poro germinativo evidente") and represents it on his drawings. However, true germ-pores have not been described in Hebeloma and the structures seen by Gennari correspond probably with a callus rather than a pore (Singer 1986; Pegler, Young 1971; Meléndez-Howell 1967). The description of Gennari is based on a single collection and can not provide any idea of the variability of the species. In conclusion, we consider as possible that $H$. mediterranea could be conspecific with $H$. domardiana.

Distribution: ITALY: Civitella in Val di Chiana, prov. Arezzo, 15.X.2002, terricolous, col lected among a mediterranean vegetation composed of Quercus ilex, Q. pubescens, Arbutus unedo, Erica scoparia, Cistus monspeliensis and C. salvifolius, leg. Silvia Urci (MCVE 669, ho lotypus) (Gennari 2003).

Hebelomina microspora Alessio and Nonis 1977, Micol. Ital. 6 (3): 19; non H. microspora Huijsman [ H. neerlandica].

Descriptions and illustrations: Alessio, Non is (1977, original description, aquarelles and photographs of the specimens). Note: Alessio (1981) mentions that the colours of the plate have not been accurately reproduced, that the aquarelles are actually of a very pale cream ivory ochre with which contrast much more coloured patches, reaching the «terra cot ta» colour; he also says the red colour of the photographs is too marked and diffuse.

The affinities of this taxon are difficult to circumscribe. The fusoid to cylindrical cheilocystidia, the top of the stem slightly white pruinose and the creamy white cap, becoming pale ochre and finally slightly brownish with irregular pale clay-orange patches are characters of Hebeloma. But, on the other hand, the ovoid to amygdaloid spores, measuring 6-8 (-9) x 4-4.5 $\mu \mathrm{m}$, and the lignicolous ecology are rather in favour of the genus Gymnopilus.

Hebelomina microspora "Huijsman ex" Alessio and Nonis 1977 is probably another species than H. microspora Huijsman [ H. neerlandica, see that species].

Distribution: ITALY: Parco della Rimembranza Augustae Taurinorum, Torino, prov. Pie monte, 5.V.1976, on slightly emergent root of Pinus strobus, alt. 500600 m, leg. Bruna Nonis (herb. E. Rebaudengo, Cebae, holotypus) (Alessio, Nonis 1977). The authors indicate «vere autumnoque», what should signify that another observation was done in autumn.

Punta Manara, Sestri Levante, prov. Liguria, 27.XII.1989, at the base of a Pinus pinaster trunk, leg. R. M. Dameri (Orsino, Traverso 1990). 
Hebelomina neerlandica Huijsman 1978, Persoonia 9 (4): 490 [nom. nov. to replace H. microspora Huijsman 1978, non H. microspora Alessio and Nonis 1977]. 三Hebelomina microspora Huijsman 1946, Rev. Mycol. NS 11: 31 [invalid, Art. 36.1]; Hebe lomina microspora Huijsman "ex Huijsman” 1978, Persoonia 9 (4): 485 [illeg., Art. 53.1] non H. microspora Alessio and Nonis (1977).

三Hebelomina huijsmaniana Singer 1986, Agaricales in Modern Taxonomy (ed. 4): 612 [illeg., Art. 52.1; nom. nov. to replace H. microspora Huijsman 1978, non H. microspora Alessio and Nonis 1977].

Descriptions: Gar nwe idner (1996), Huijs m a n (1946, 1978, original description), Ne ville, Roux (1997), S pooner (1993), Volders (1997), Urbonas (2005).

ILLUSTRATIONS: A n o ny m ou s (2003, colour photograph of the specimens), Garnweidne r (1996, colour photograph of the specimens and line drawings of spores and cheilocystidia), Huijs man (1946, line drawings of microscopic characters of the typus; 1978, line drawings of the type specimens), Neville and Roux (1997, colour photograph and line drawings of microscopic characters), S p o o n e r (1993, line drawings of spores and cheilocystidia), Vol d e r s (1997, line drawings of microscopic characters; the author also mentions a slide JVDM 7677 and an aquarelle O. Van De Kerckhove 295, BR, both unpublished), U r b o n a s (2005, line drawings of microscopic characters).

The publication of a valid name for this taxon has not been easy. The species is first described by Huijs man (1946), under the name Hebelomina microspora. Unfortunately, no Latin diagnosis is provided and the name is thus invalid (Art. 36.1).

About thirty years later, Alessio and Non is (1977) publish a latin diagnosis in order to validate the name created by Huijsman. However, they choose another type than the specimen cited by Huijsman and, consequently, at a nomenclatural point of view, they create a new taxon. On the other hand, as pointed out by different authors (a.o. Huijsman 1978; Neville, Roux 1997), there are several morphological differences between the two specimens : the Italian collection has a inocyboid habit, reddish brown colours on the pictures, amyloid spores and twice bigger cheilocystidia. Therefore, they probably belong to two different taxa at a systematic point of view as well. That hypothesis is not accepted by Alessio (1981), who believes that a single taxon is involved. We consider that conspecificity possible, while unlikely.

A few months after Alessio and Nonis (1977) and Huijsman (1978) also decides to validate his species by publishing a Latin diagnosis. His paper is at the point to be sent to the printer when he discovers the "validation" made by Alessio and Nonis. He publishes nevertheless his own "validation" (which is illegitimate: later homonym, Art. 53.1) but, thinking that his fungus is not the same that the one of the Italian authors, he adds, at the end of his text, a note in which he proposes $\mathrm{He}$ belomina neerlandica as a new name for his species. Would the synonymy be proven in the future, then the species should be named $H$. microspora Alessio and Nonis and $H$. neerlandica would be reduced to a superfluous synonym.

Finally, Singer (1986), reading the Huijsman (1978) paper, overlooks its final note and introduces Hebelomina huijsmaniana as a new name to replace $H$. microspora Huijsman. The name published by Singer is illegitimate (superfluous name, Art. 52.1).

The nomenclatural changes are not finished yet. The species will probably be transferred to the genus Gymnopilus, since molecular analyses have shown that the species is likely a white spored Gymnopilus, rather close to G. penetrans (Moncalvo et al. 2002: 367, 379). Regarding the macro- and microscopic characters of 
the species as well as its ecology on Pinus wood, it seems reasonable to consider H. microspora as a whitish Gymnopilus, with white and smooth spores. Within that genus, the absence of a membranous ring, the relatively small size of the spores and the growth on coniferous wood correspond with the group of G. stabilis, G. sapineus, G. penetrans and $G$. hybridus. The status of the three last species is still uncertain and varies considerably in the recent literature: three (Moser 1983; Orton 1993) or two independent species (Holec 2005) or one single species (Høiland 1990).

Distribution: BELGIUM: Bois des Manants, Tilff, prov. Liège, 6.X.1978, 31.X.1978 and 5.X.1979, on dead wood of Pinus sylvestris (branches of various size, stumps, cones), herb. V. Demoulin (LG). "De Kuik", Gooreind (Wuustwezel), prov. Antwerpen, 9.XI.1996, in a pine wood on sandy soil, on fallen branches and litter of Pinus nigra, herb. O. Van De Ker ckhove 499 (BR), J. Volders 96205 and A. de Haan 96100 (Volders 1997). The species has been found every year at the same place up to the year 2000 (de Ha n 2001). FRANCE: "Croix de Novy", Monregard, dépt. Haute Loire, 23.IX.1993, on a piece of rotten coniferous wood (Picea abies, Abies alba or Pinus sylvestris), leg. A. Ch a r r e t (herb. P. Neville 93.09.20.25 and P. Roux 93.09.17.57) (Neville, Roux 1997). Forêt de Pont Calleck, dépt. Morbi han, X.2002, on rotten wood of Pinus, two collections leg. P. Hériveau and leg. R. Chalange (herb. M. Chiaffi) (An onym ous 2003 and G. Eys s a r ti e r, comm. pers.). GERMANY: Schöngeising, near Fürstenfeldbruck, distr. Oberbayern, 13.XI.1994 and 1.X.1995, on a dead Larix decidua trunk, herb. E. Garnweidner (G a r n w e i d n e r 1996). LITHUANIA: Žagarés forest, Joniškio distr., 20.IX.1990, on fallen rotting branches Strinišku forest, Vilkaviškio distr., 25.VII.1999, on fallen rotting branches (U rbon as 2005: 174) NETHERLANDS: Near Rijssen, prov. Overijssel, 24.X.1943, on dead twigs of Pinus sylvestris, coll. W.J. Reuve camp and W.F. Smits (L, holotypus) (Hu ij s m a n 1946, 1978). The growth place has been de stroyed soon after 1945, when a new quarter of Rijssel was built; moreover, the typus has been found in a very poor condition, badly moth eaten and mouldy (Huijs m an 1978). «De Fonteintjes», south of Rijssen, 1988, under Picea abies, coll. C. Bas, and 1990, leg. W. Ligterink (L) (unpublished data, cited fide Volders 1997; Arnolds, Kuyper and Noordeloos 1995; see also the distribution map in An on y m o u s 2000). UKRAINE: forest near Novo bilychi (Kiev), Kiev obl., 14.IX.2004, on dead log of Pinus sylvestris lying on the ground, herb. A. Fraiture 2927 (BR) and V. Hayova (KW 29993) (this publication). UNITED KINGDOM: Surrey, Oxshott Heath, nr bog N of Sandy Lane, 14.X.1984, under Pinus and Betula on damp sandy ground, coll. L. Spooner (K) Ibid., 13.X.1991, on dead twig in litter, herb. Kew (K) (S pooner 1993). South Hampshire, 1999, clustered on fallen branch of Salix (BMSFRD $\mathrm{n}^{\circ} 480383$ ). North Hampshire, 1999, on mossy fallen branch of Salix in broadleaf semi natu ral woodland (BMSFRD n 493526) (British Mycological Society Fungus Record Database).

Hebelomina pallida Dessi and Contu 1993, in Contu and Dessi, Micol. Veget. Medit. 8 (2): 104.

Descriptions And illustrations: Contu, Dessi (1993, original description, with colour photograph [the legend of which erroneously mentions (Hebelomina candida) and habit sketch of the carpophores and line drawings of the spores, basidia and cheilocystidia).

The authors of the species point out that $H$. pallida is close to $H$. neerlandica and they list the following characters to separate the two species: the carpophores of $H$. pallida have a white colour remaining nearly unchanged during their whole life, they are completely devoid of a veil even in very young stage, they have bigger and non amygdaliform spores and they grow on dead wood of Eucalyptus. Those differences are not much significative. $H$. neerlandica is also a whitish species and the colour modifications described by Huijsman (becoming pale ochraceous-aluta- 
ceous, often more or less mixed with incarnate) may considerably vary depending on ecological conditions. The veil of that species is fugacious and often difficult if not impossible to see. As for the spore size, the figures are indeed a bit bigger: 7.5-9.0 (-10.3) x 5.2-6.0 (-6.9) $\mu \mathrm{m}$ for $H$. pallida versus 6.5-7.8 x 4.2-4.6 $\mu \mathrm{m}$ for H. neerlandica (Huijsman 1978), but some collections of the latter species have shown bigger spores (a.o. Vold e rs 1997). The difference between the two species is mainly significative for the spore width. Since the estimation of the spore length/width ratio (Q) for $H$. pallida is about 1.47 when calculated on the spore size reported by Contu, Dessi (1993) and about 1.77 when calculated after the drawings provided by the same authors, it seems possible that the spore size given by Dessi and Contu is not perfectly accurate. The habitat on Eucalyptus wood is indeed unusual but not sufficient to create a new species. In conclusion, we think that $H$. pallida is very close to $H$. neerlandica and even possibly conspecific with that species.

Distribution: ITALY: Serramanna, prov. Cagliari, Sardinia, 05.XII.1992, on dead wood of Eucalyptus camaldulensis, herb. M. Contu 92/269 (CAG, holotypus) Ibid., 06.XII.1992 and 10.I.1993, leg. P. Dessi and M. Contu (CAG and pers. herb. P. Dessi, paratypus) (Contu, Dessi 1993).

\section{IDENTIFICATION KEY TO THE SPECIES DESCRIBED IN HEBELOMINA}

1) Cheilocystidia absent. Carpophores reddish brown to orange brown. India. H. maderaspatana

1) Cheilocystidia abundant. Carpophores usually much paler, often whitish. Europe, Algeria 2

2) Terricolous species. Spores bigger than $9 \times 6 \mu \mathrm{m}$, often more or less citriform or with a pap illate top. Cheilocystidia mostly cylindrical or clavate, sometimes narrowly lageniform (Hebelomoid species) 3

2) Lignicolous species. Spores smaller than 9 × $6 \mu \mathrm{m}$, usually amygdaliform or ellipsoid and not citriform. Cheilocystidia mostly narrowly lecythiform, except in H. microspora, where they are fusoid to cylindrical. (Gymnopiloid species) 4

3) Cap $57 \mathrm{~cm}$ broad. Spores 911 ( 12) $\mu \mathrm{m}$ long. Italy. H. mediterranea

3) Cap $2.54 \mathrm{~cm}$ broad. Spores $1115 \mu \mathrm{m}$ long. Algeria and Baltic countries.

H. domardiana

4) Spores amyloid. Cheilocystidia bigger than $40 \times 9 \mu \mathrm{m}$, mostly fusoid to cylindrical. On pine wood. May and December. Italy H. microspora 4) Spores dextrinoid. Cheilocystidia smaller than $40 \times 9 \mu \mathrm{m}$, mostly narrowly lecythiform. On coniferous wood or on Eucalyptus. September January. Europe

5) Spores (3.5 ) 4.05 .0 ( 5.2) $\mu \mathrm{m}$ wide. Carpophores whitish, becoming pale ochraceous al utaceous or incarnate. On coniferous wood, rarely on Salix. (September ) October Novem ber. Europe. H. neerlandica

5) Spores 5.26 .0 ( 6.9) $\mu \mathrm{m}$ wide. Carpophores whitish and remaining so. On Eucalyptus wood. December January. Italy H. pallida 


\section{SUMMARY AND CONCLUSIONS}

The genus Hebelomina is heterogenous. It can be divided into at least two groups of species.

1) The hebelomoid species (H. domardiana and H. mediterranea). They are terricolous and probably ectomycorrhizal, with a tricholomoid or hebelomoid habit, a stem which is pruinose in its upper part, rather big spores (usually above $9 \times 6 \mu \mathrm{m}$ ), more or less citriform or amygdaliform with a papillate top, cheilocystidia usually irregularly cylindrical or clavate, eventually narrowly lageniform but not lecythiform. Both species have been described from Mediterranean oak forests but, rather unexpectedly, the first one has also been reported from the three Baltic countries, in pine forests and in mixed forests. The two species are very close to the genus $\mathrm{He}$ beloma. This has been recently confirmed by molecular analysis for $H$. domardiana (specimen from Estonia), which has consequently been transferred to that genus (Vesterholt 2005). We suggest that the two species are close to each other and even possibly conspecific. On the other hand, the Baltic collections attributed to $H$. domardiana could belong to a separate, undescribed species of this group.

2) The gymnopiloid species (H. neerlandica, $H$. pallida and probably $H$. microspora). They are lignicolous and saprotrophic, with a gymnopiloid habit, a stem not or only slightly pruinose, medium sized to small spores (usually under $9 \times 6 \mu \mathrm{m}$ ), which are amygdaliform, ellipsoid or ovoid and neither citriform nor papillate; the cheilocystidia are usually narrowly lecythiform. Most of the collected specimens of $H$. neerlandica were growing on coniferous wood, mainly Pinus sylvestris, but also $P$. nigra, Larix decidua and Picea abies; there are two reports on Salix in Great Britain. H. microspora has been observed on wood of Pinus strobus and P. pinaster. H. pallida is only known from the type collections, on wood of Eucalyptus camaldulensis. By its morphological characters, $H$. neerlandica is very close to Gymnopilus. This has been confirmed by molecular analysis (Moncalvo et al. 2002) and the species will probably be transferred to that genus. $H$. pallida is very close to $H$. neerlandica and could even be conspecific. We believe that $H$. microspora belongs to this same group; however, its taxonomic position is less easy to interpret.

3) Incertae sedis (H. maderaspatana). This species exhibits characters from the two groups cited above and, besides, the lack of cheilocystidia does not fit with the genera Hebelomina, Hebeloma and Gymnopilus. The taxonomic position of the species is thus still unclear.

In conclusion, it seems probable that most of the species of the genus Hebelomina will be transferred to either Hebeloma or Gymnopilus and that the genus Hebelomina will disappear. It is nevertheless noteworthy that most of the species described in Hebelomina share some original characteristics which separate them from those two genera. The carpophores are often whitish or very pale, at least when young. The spores are very particular, being whitish and smooth under the light microscope when the spores in Hebeloma and Gymnopilus are brown and rather coarsely ornamented. It seems that it is difficult to obtain a good spore print because the spores, while being usually produced in large amount, are remaining on the gills. When it was possible to obtain a spore deposit from a Hebelomina collection, it has been observed that it was not pure white but very pale brownish. The pictures of the spores of $H$. neerlandica, seen by SEM (Fig. 2) show a kind of shallow ornamentation although it could be an 
artefact due to insufficient reinflation. The presence of those special features in the different Hebelomina species could be explained by a mutation, inducing the loss of pigmentation of the carpophores and changing the brown and ornamented spores of Hebeloma and Gymnopilus into whitish and smooth "hebelominoid" spores.

An unpublished paper by Gasparini (pers. comm.) has drawn our attention to the genus Rapacea, created by Hor ak (1999) to accommodate a single species, Rapacea mariae E. Horak. It is a cortinarioid species, recorded from New Zealand, Tasmania and Papua New Guinea, which seems to be another example of this "hebelominoid syndrome", again affecting a species of the Cortinariaceae family. It has whitish carpophores (see colour picture in Soop 2005) and its spores are pale olivaceous-argillaceous, i.e. much paler than the normal colour of the spores in the genus Cortinarius. They are inamyloid, but become brown in Melzer's reagent ( dextrinoid), and appear smooth under the light microscope but minutely asperulate or with low net-like ridges under SEM. Molecular and phylogenetic analyses have shown that Rapacea was nested in the genus Cortinarius (Peintne r et al. 2002a) and, consequently, the species has been transferred to that genus: Cortinarius mariae (E. Horak) E. Horak et al., in Peintner et al. (2002b: 449).

Acknowledgements. The authors thank the mycologists who sent them information through the internet forum Mycologia Europaea, particularly G. Eyssartier, for the unpublished de scription of a collection, and P. Bertea and J. M. Trendel, for the localization of the forêt de l'Alma. They also thank H. Beker for the interesting discussion concerning the topic, V. Demoulin (LG) for providing copies of three articles and giving access to his specimens, $G$. Adamonyte and J. Kasparavicius (BILAS) for sending copy of a reference and B. Gasparini for the communication of an unpublished paper. They are grateful to O. Van de Kerckhove (BR) for preparing the drawings for publication, M. Verhaegen (BR) for taking the pictures with the electronic microscope and D. Aplin (BR) for helping to solve some questions about English language.

\section{REFERENCES}

Aless i o C.L., No n is U. 1977. Una specie quasi sconosciuta: Hebelomina microspora. Micol. Ital. 6 (3): $1519+$ pl. 18 .

Alessi o C.L. 1981. Revisione di miei lavori comparsi nei primi 25 numeri di Micologia Italiana. Micol. Ital. 10 (1): 2127.

An onymous 2000 . Kaartenbijlage Overzicht van de paddestoelen in Nederland, 2 vols. Nederlandse Mycologische Vereniging, Baarn. $349+329$ pp.

An o n y m o u s “2003”, 2004. Session de la Société Mycologique de France à Guidel (Morbihan) du 21 au 26 octobre 2002. Bull. trim. Soc. mycol. Fr. 119 (3/4): 385402.

Arnolds E., Kuyper Th.W., Noordeloos M.E. (eds). 1995. Overzicht van de paddestoelen in Ned erland. Nederlandse Mycologische Vereniging, Wijster. 871 pp. +16 pl. coul.

BMSFRD (British Mycological Society Fungal Records Database) http://194.203.77.76/fieldmycology/ BMSFRD/bmsfrd.asp

Cont u M., Dessi P. 1993. Una nuova specie di Hebelomina dalla Sardegna meridionale. Micol. Veget. Medit. 8 (2): 101106.

de Haan A. 2001. Twee interessante en zeldzame plaatjeszwammen in onze provincie. Ankona Nieu wsbr. 4 (13): 2.

Garnweidner E. 1996. Hebelomina neerlandica Huijsman Erstfund für Deutschland. Mycol. Ba varica 1: 1520.

Gennari A. "2002”, 2003. Una nuova specie di Hebelomina dall'Italia. Chiave per la determinazione delle specie sinora descritte. Riv. Micol. 45 (4): 311318.

Høil and K. 1990. The genus Gymnopilus in Norway. Mycotaxon 39: 257279. 
Holec J. 2005. The genus Gymnopilus (Fungi, Agaricales) in the Czech Republic with respect to collec tions from other European countries. Acta Mus. Nat. Pragae, Ser. B, Hist. Nat. 61 (1/2): 152.

Horak E. 1968. Synopsis generum Agaricalium (Die Gattungstypen der Agaricales). Beitr. Kryptoga menfl. Schweiz 13: 1741.

Horak E. 1999. New genera of Agaricales (Basidiomycota), 1 Rapacea gen. nov. Kew Bull. 54 (3): 789794.

Hu ijs m a n H.S.C. 1946. Hebelomina microspora nov. spec. Rev. Mycol, NS 11 (1): 3133.

Huijs man H.S.C. 1978. Hebelomina microspora Huijsm. and reflexions on Hebelomina R. Maire as a genus. Persoonia 9 (4): 485490.

Maire R. 1935. Un nouveau genre d'Agaricacées. Bull. Soc. Hist. nat. Afr. N. 26 (1): 1315.

Meléndez Howell L. M. 1967. Recherches sur le pore germinatif des basidiospores. Ann. Sci. nat., Bot., Sér. 12, 8: 487638.

Moncalvo J. M., Vilgalys R., Redhead S.A., Johnson J.E., James T.Y., Aime M.C., Hofs tetter V., Verduin S.J.W., Larsson E., Baroni T.J., Thorn R.G., Jacobsson S., Clé mençon H., Mille r O. K. Jr. 2002. One hundred and seventeen clades of euagarics. Mol. Phylo genet. \& Evol. 23: 357400.

Mos e r M. 1983. Kleine Kryptogamenflora IIb2: Die Röhrlinge und Blätterpilze (Polyporales, Boletales, Agaricales, Russulales), 5 Aufl. G. Fischer Verlag, Stuttgart. 533 pp.

Nat a rajan K., Raman N. 1980. South Indian Agaricales, 13. Kavaka 8: 6972.

Natarajan K., Raman N. 1983. South Indian Agaricales. A preliminary study of some dark spored species. Bibl. mycol. 89: 1 203. J. Cramer, Vaduz.

Neville P., Roux P. 1997. Hebelomina neerlandica Huijsman Première récolte française et deuxième station connue d'un très rare Agaricomycetidae. Bull. Féd. mycol. Dauphiné Savoie 37 (144): 35 46.

Nezdoiminogo E.L. 1996. Handbook of Fungi of Russia. Order Agaricales. Vol. 1. Family Cortina riaceae. Nauka, St Petersburg. 408 p. (in Russian)

Orsino F., Traverso M. 1990. Contributo alla conoscenza della flora micologica ligustica, 8. Micol. ital. 19 (2): 1116.

Orton P.D. 1993. Gymnopilus. (In:) R. Watling, N.M. Gregory (eds). British Fungus Flora, Agarics and Boleti, 7 Cortinariaceae p.p.: 58 72. Royal Botanic Garden Edinburgh.

Pegler D.N., Young T.W.K. 1971. Basidiospore morphology in the Agaricales. Beih. Nova Hedw. 35: vi, 210 pp. +53 pl.

Peintner U., Horak E., Moser M., Vilgalys R. 2002a. Phylogeny of Rozites, Cuphocybe and Rapa cea inferred from ITS and LSU rDNA sequences. Mycologia 94 (4): 620629.

Peintner U., Horak E., Moser M., Vilgalys R. 2002b. Rozites, Cuphocybe and Rapacea are taxo nomic synonyms of Cortinarius: new combinations and new names. Mycotaxon 83: 447451.

Singer R., Araujo I.J.S. 1979. Litter decomposition and ectomycorrhiza in Amazonian forests, 1 A comparison of litter decomposing and ectomycorrhizal Basidiomycetes in latosol terra firme rain forest and white podzol campinarana. Acta Amazonica 9 (1): 2541.

Singer R. 1986. The Agaricales in modern taxonomy (4th ed.). Koeltz Scientific Books, Koenigstein, viii, 981 p. +88 pl.

S o op K. 2005. Cortinarioid Fungi of New Zealand. An iconography and key (4th ed.). Scientrix, Mora, 100 pp.

S pooner B.M. 1993. Hebelomina neerlandica Huijsman in Persoonia 9: 490 (1978). Mycologist 7 (3): 108.

Urbonas V. 2005. Nuosedieciai (Cortinariales). Lietuvos Grybai 8 (5): 288 pp. + 32 pl.

Urbonas V., Kalamees K., Lukin V. 1986. Conspectus Florum Agaricalium Fungorum (Agaricales s.1.) Lithuaniae, Latviae et Estoniae [ed. 2]. Mokslas, Vilnius. 140 pp.

Vesterholt J. 2005. The genus Hebeloma. Fungi of Northern Europe 3: 1 146. Svampetryk, Tilst, Danemark.

Volders J. 1997. Hebelomina neerlandica Huijsman, de Witspoorvaalhoed, een nieuwe soort en genus voor België. AMK Meded. 97 (1): 25. 


\section{Hebelomina neerlandica, gatunek nowy dla Ukrainy i rozważania o rodzaju Hebelomina}

\section{Streszczenie}

Owocniki Hebelomina neerlandica Huijsman zostały niedawno zebrane w okolicach Kijo wa. Ten nowy dla Ukrainy gatunek został opisany i zilustrowany przez autorów, którzy rów nocześnie dyskutują pozycję taksonomiczną rodzaju, a w nim sześciu dotychczas znanych ga tunków. Są to: H. maderaspatana, H. mediterranea, H. domardiana, H. microspora, H. pallida, H. neerlandica.

Praca zawiera klucz do oznaczania, analizę literatury, na podstawie której rozważana jest delimitacja taksonów, nazewnictwo, cechy taksonomiczne i rozmieszczenie. W większości są to gatunki rzadko spotykane, niektóre znane tylko z pojedynczych okazów.

Dokładne wyjaśnienie wielu kwestii poruszanych przez autorów wymaga dalszych zbio rów, do których zachętą może być niniejsza praca. 